\title{
An Introduction to the Special Issue "Geochemical Processes of Karst and Karst Paleoenvironments" as Part of the International Year of Caves and Karst
}

\author{
George Veni
}

Citation: Veni, G. An Introduction to the Special Issue “Geochemical Processes of Karst and Karst Paleoenvironments" as Part of the International Year of Caves and Karst. Water 2022, 14, 91. https://doi.org/ 10.3390/w14010091

Received: 19 December 2021 Accepted: 27 December 2021 Published: 4 January 2022

Publisher's Note: MDPI stays neutral with regard to jurisdictional claims in published maps and institutional affiliations.

Copyright: (C) 2022 by the author. Licensee MDPI, Basel, Switzerland. This article is an open access article distributed under the terms and conditions of the Creative Commons Attribution (CC BY) license (https:// creativecommons.org/licenses/by/ $4.0 /)$.
National Cave and Karst Research Institute, Carlsbad, NM 88220, USA; gveni@nckri.org; Tel.: +1-575-887-5517

\section{The International Year of Caves and Karst}

About $15.4 \%$ of Earth's land surface is karstifiable rock. Carbonate rocks comprise $15.2 \%$ of the land surface [1] and evaporites $0.2 \%$ [2]. The expanse of karst buried under other units, still important as water supplies and which may be at risk for land subsidence and other concerns, is undefined but clearly a significantly large area. An estimated 16.5\% of the global population lives on karst [1]. Caves, both karstic and pseudokarstic, harbor many of the world's great archaeological and paleontological sites and often hold the highest endemic biodiversity. Caves are also gaining recognition as containing the richest and most diverse paleoclimate records (e.g., [3]).

The International Year of Caves and Karst is an event organized by the International Union of Speleology to educate the world about the importance and challenges of caves and karst areas. Initially organized for 2021, it is extended through 2022 due to the COVID-19 pandemic. At the time of this writing near the end of 2021, 258 partner organizations in 50 countries have joined the International Year effort and conducted over 370 events, reaching and teaching tens of millions of people globally about caves and karst. All International Year activities are recorded at www.iyck2021.org (accessed on 26 December 2021).

This Special Issue of Water addresses an important International Year event. Over the past 20 years, the number of universities with karst programs and professors possessing karst expertise has increased dramatically, yet their numbers remain relatively small and many geoscientists remain untrained in cave and karst science. This Special Issue makes a needed contribution toward continuing to increase awareness and understanding of caves and karst in the geoscience community. Given that karst is a terrain formed predominantly by dissolution and that caves hold rich paleoclimatic records, this issue's focus on karst geochemical and paleoenvironmental processes is quite fitting.

\section{The Role of Geoscience in the International Year}

Caves and karst are geologic features. Consequently, most aspects of the International Year of Caves and Karst event are linked to geosciences. Great emphasis is often placed on karst groundwater resources. Karst aquifers are the primary or sole water supply for approximately 678 million people [4] and are widely recognized as the aquifers most vulnerable to pollution and depletion. Sinkhole subsidence and collapse are also commonly acknowledged as significant geohazards associated with karst, although given their irregular occurrence temporally and geographically, few people are aware of their high costs. In the USA, damage to roadways alone (excluding property and other damage) averages over USD 300 million annually [5].

The topics of this Special Issue seem less urgent in comparison, yet they are highly relevant to societal and scientific needs. Karst geochemistry was long considered an academic exercise, valuable to quantifying and classifying surface landforms and aquifer permeabilities. Over the past 20 years, it has become a critical component in understanding 
the role of karst in the global carbon cycle and its short and long-term potential for natural and artificial carbon sequestration (e.g., [6]).

Calcite speleothems sequester carbon for millennia and, in the process, serve as proxies that record past climates. Atmospheric temperature and humidity are most commonly gleaned from speleothems and with increasing precision and resolution. More recently, pollens, spores, phytoliths, and windblown dust are found trapped in the calcite, yielding often unique paleoenvironmental data (e.g., [3]).

A long-neglected area of study is cave sediments. Historically, sediments were studied for bones and cultural materials, which certainly can offer unique paleoenvironmental information. More recent investigations use cave sediments to reconstruct paleo-landscapes and aquifers, and they characterize the processes that created and denuded them (e.g., [7]). Karst critical zone studies are a nascent field that connects all the above topics and more into a comprehensive model of karst processes within global cycles.

Some of these topics are covered in the exciting papers received so far and planned for this Special Issue. Low-Calcium Cave Dripwaters in a High $\mathrm{CO}_{2}$ Environment: Formation and Development of Corrosion Cups in Postojna Cave, Slovenia demonstrates the importance of detailed and wholistic monitoring of caves (hydrological, geochemical, mineralogical, and meteorological) in unraveling complex patterns of calcite deposition with a view toward more effective interpretation of paleoenvironmental records.

The two papers currently planned seem equally informative. Study of the Trends of Chemical-Physical Parameters in Different Karst Aquifers: Some Examples from Italian Alps, should provide consequential insights on karst groundwater and geochemical evolution between different hydrogeologic settings. Holocene Sedimentary Record and Impact of SeaLevel Rise in the Karst Lake Velo Blato and Wetlands on Pag Island (Croatia) is poised as a much-needed contribution to cave sediment studies. I eagerly look forward to these and other contributions.

\section{Looking beyond the International Year}

This Special Issue of Water will doubtlessly have both an immediate and long-term impact on science, as is the case with all well-developed research papers. What sets this issue and its papers apart from other journals is its connection to a broader body of work that collectively constitutes the International Year of Caves and Karst. After the year closes at the end of 2022, all results of the International Year events-journal papers, books, workshops, conferences, governmental proclamations, cave clean-ups, classes, etc.-will be synthesized into a summary document. Everyone will be able to use that summary to continue promoting the theme of the International Year- "Explore, Understand, Protect" decades into the future. It is my fervent hope that young scientists, in particular, build on the work developed in this issue and other International Year efforts.

As President of the International Union of Speleology, I encourage and invite all scientists, land managers, policymakers, educators, and members of the general public to learn more about the diverse significance of caves and karst. Please join the International Year of Caves and Karst in whatever way possible for you to teach your part of the world about these amazing regions and natural resources.

Funding: The preparation of this introduction to this Special Issue received no external funding.

Informed Consent Statement: Not applicable.

Data Availability Statement: This introduction is not a research report with substantial specific supporting data beyond the reports cited. Instead, it is an overview of the historical and state-of-theart cave and karst geoscience. For open access to the general karst literature, visit www.karstportal.org (accessed on 26 December 2021).

Conflicts of Interest: The author declares no conflict of interest. 


\section{References}

1. Goldscheider, N.; Chen, Z.; Auler, A.S.; Bakalowicz, M.; Broda, S.; Drew, D.; Hartmann, J.; Jiang, G.; Moosdorf, N.; Stevanović, Z.; et al. Global distribution of carbonate rocks and water resources. Hydrogeol. J. 2020, 28, 1661-1677. [CrossRef]

2. Hollingsworth, E. Karst Regions of the World (KROW)-Populating Global Karst Datasets and Generating Maps to Advance the Understanding of Karst Occurrence and Protection of Karst Species and Habitats Worldwide. Master's Thesis, University of Arkansas, Fayetteville, NC, USA, May 2009.

3. Johnson, K.R.; Feinburg, J.M. Speleothems. Elements 2021, 17. Available online: http:/ / elementsmagazine.org/past-issues/ speleothems / (accessed on 26 December 2021).

4. Stevanović, Z. Karst waters in potable water supply: A global scale overview. Environ. Earth Sci. 2019, 78, 662. [CrossRef]

5. Weary, D.J. The cost of karst subsidence and sinkhole collapse in the United States compared with other natural hazards. In National Cave and Karst Research Institute Symposium 5, Proceedings of the 14th Multidisciplinary Conference on Sinkholes and the Engineering and Environmental Impacts of Karst, Rochester, MN, USA, 5-9 October 2019; National Cave and Karst Research Institute: Carlsbad, NM, USA, 2015. Available online: https://digital.lib.usf.edu/SFS0053749/00001 (accessed on 26 December 2021).

6. Veni, G. A framework for assessing the role of karst conduit morphology, hydrology, and evolution in the transport and storage of carbon and associated sediments. Acta Carsologica 2013, 42, 203-211. Available online: https: / /ojs.zrc-sazu.si/carsologica/ article/view / 662 (accessed on 26 December 2021). [CrossRef]

7. Bosch, R. Landscape Evolution of the Central Kentucky Karst. Ph.D. Thesis, University of Cincinnati, Cincinnati, OH, USA, 2021. 